\title{
The concept of the new information system of electronic services in the field of land and property relations
}

\author{
Zakhar Zakharov $^{1 *}$, Alexander Kryakhtunov ${ }^{1}$ \\ ${ }^{1}$ Department of Geodesy and Cadastral Activities, Industrial University, Lunacharskogo \\ Street, Building 2, Room 103, Tyumen, 625000, Russia, zaharOFFM@mail.ru
}

\begin{abstract}
The article describes the concept of a new geographic information system for the provision of electronic state and municipal services. The problem of the lack of an open portal in the Internet for choosing unencumbered and suitable for use for the intended purpose land plots is considered. The importance of information systems in the development of the digital economy and information society in the Russian Federation is shown. The analysis of existing geographic information systems is given in a generalized and systematic way. As a result, it was found that the main drawback of the existing systems is the limitation of a certain territory and a set of services. It is concluded that it is necessary to display the free land. Automatic notifications should be sent to the competent authorities. The new information system should have direct and feedback links with all information and geographic information systems in operation and being developed in Russia. The results and conclusions are applicable to the creation of new geographic information systems.
\end{abstract}

\section{Introduction}

The lack of an open portal for the selection of free and usable state and municipal land plots on the Internet limits the ability of citizens and entrepreneurs to obtain land resources.

The Portal of Public Services operating in Russia allows you to apply for land plots. However, the applicant must choose the land plot of interest. The selected land plot can be burdened with the rights of third parties, have a restriction in use.

The urgency of creating a new information system is the need for the transition to the digital economy and the development of the information society in the Russian Federation. Data in digital form is a key factor of production in all spheres of socio-economic activity, which increases the competitiveness of the country, the quality of life of citizens, ensures economic growth and national sovereignty [1]. The main way to ensure the efficiency of the digital economy is the introduction of data processing technology. [2]

The issue of increasing the revenues of the federal and regional budgets through the sale of land plots, the vast majority of which have not yet been privatized, also remains relevant. According to the state statistical observation carried out by Rosreestr, at the beginning of 2018 the area of land owned by the state and municipal property amounted to about 92 percent of the land fund of the country. 
The distribution of land by form of ownership is shown in figure 1.

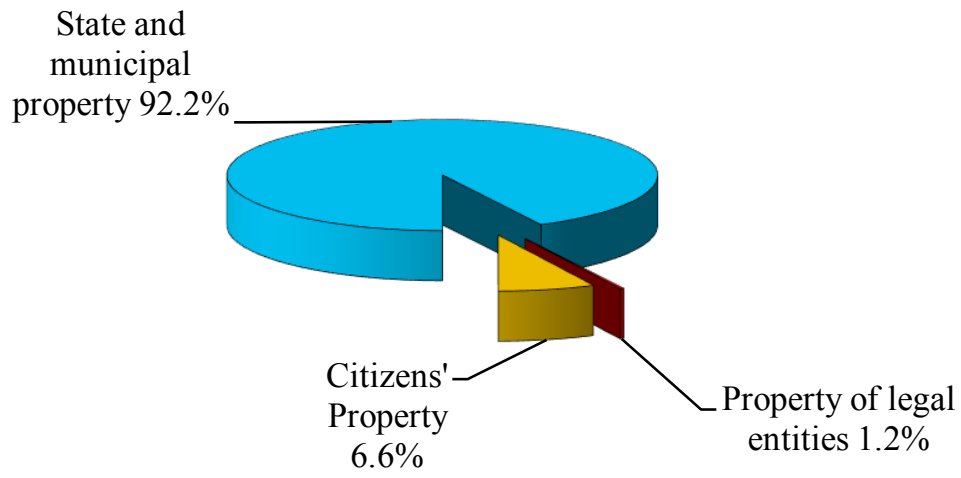

Fig. 1. The distribution of land in Russia by type of ownership (as of 01/01/2018) [3].

\section{Methodology}

The object of this study are land and property relations. The subject of the research is the use of geographic information systems for the provision of electronic state and municipal services.

In a broad sense, a geographic information system is a system for collecting, storing, analyzing and graphing visualization of spatial (geographic) data and related information about necessary objects. [4]

The purpose of the work is to develop a concept of a geographic information system that will expand the capabilities of citizens and entrepreneurs in obtaining land. The concept that will shift the vector from the declarative nature of the provision of services to land management by stimulating the authorities to involve land in economic circulation. The objectives are to provide a comparative analysis of existing geographic information systems, to identify the causes of their advantages and disadvantages, to develop a new concept.

In the course of this study, the method of analysis was applied. The analysis of existing geographic information systems is given in a generalized and systematic way.

\section{Results and discussion}

Currently, there is no information on the priority of citizens to obtain land for the construction of individual houses and garden plots in the public domain. These data are stored in separate "silos" in the local self-government bodies and public authorities. It is necessary to create a single open list of citizens who want to receive land resources to analyze the situation and make competent management decisions. The preliminary analysis shows the high demand of citizens and the shortage of land plots requested by them. The creation of a new information system will allow state and local authorities to promptly conduct auctions for the provision of land ownership and lease, to provide land without bidding, to carry out in the prescribed manner the transfer of land from one form of ownership to another, from one category to another, to change the type of permitted use. The authorized bodies will be able to respond quickly to the needs of citizens, entrepreneurs, ensure sustainable development of territories with the preservation or creation of new recreational areas. 
Consider existing geographic information systems with similar tasks. The interface of the Public cadastral map is shown in figure 2. Geographic information system allows you to determine the exact location and configuration of the land. In contrast to the information system being developed, the Public cadastral map does not provide information on encumbrance of the rights of third parties to land plots and restrictions on their use. [5]

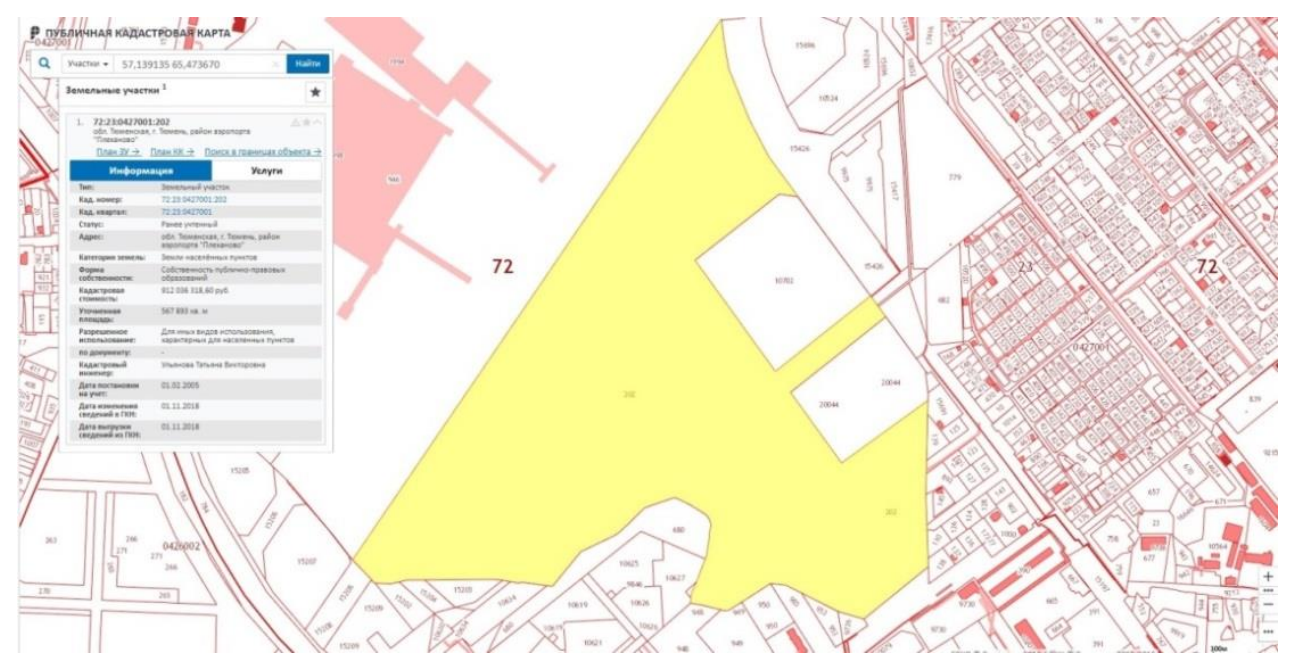

Fig. 2. The Public cadastral map.

The cartographic base is represented by satellite images ("Esri" and "ScanEx") and the unified electronic cartographic base [6]. One of the ways to obtain data is to create an electronic request indicating the type of object and universal id - number of the site, which coincides with the cadastral number. As a result, you can get information about the coordinates of land plots. [7]

Currently, there are two regional information systems with similar tasks. The first is a Database of the priority of citizens to obtain ownership (rent) of land owned by the Republic of Crimea or municipal property (AIS "Land" 2.0), presented in figure 3. AIS "Land" 2.0 collects, organizes and stores information on the provision of land for individual housing construction on the territory of the Republic of Crimea, including personal data of applicants, data of title documents, information about the construction of land. [8]

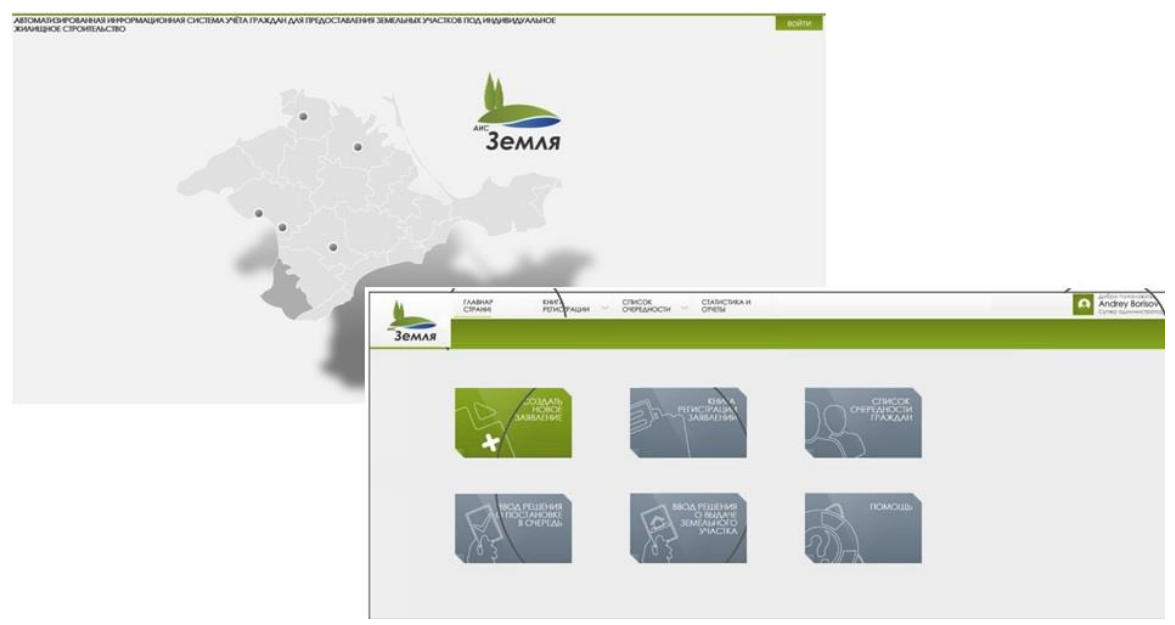

Fig. 3. The AIS "Land" 2.0. 
The second is the Federal information system "To the far East", presented in figure 4. It was created to ensure the implementation of the Federal law known as the Law on the far Eastern hectare. The operator of the information system is the body of registration of rights

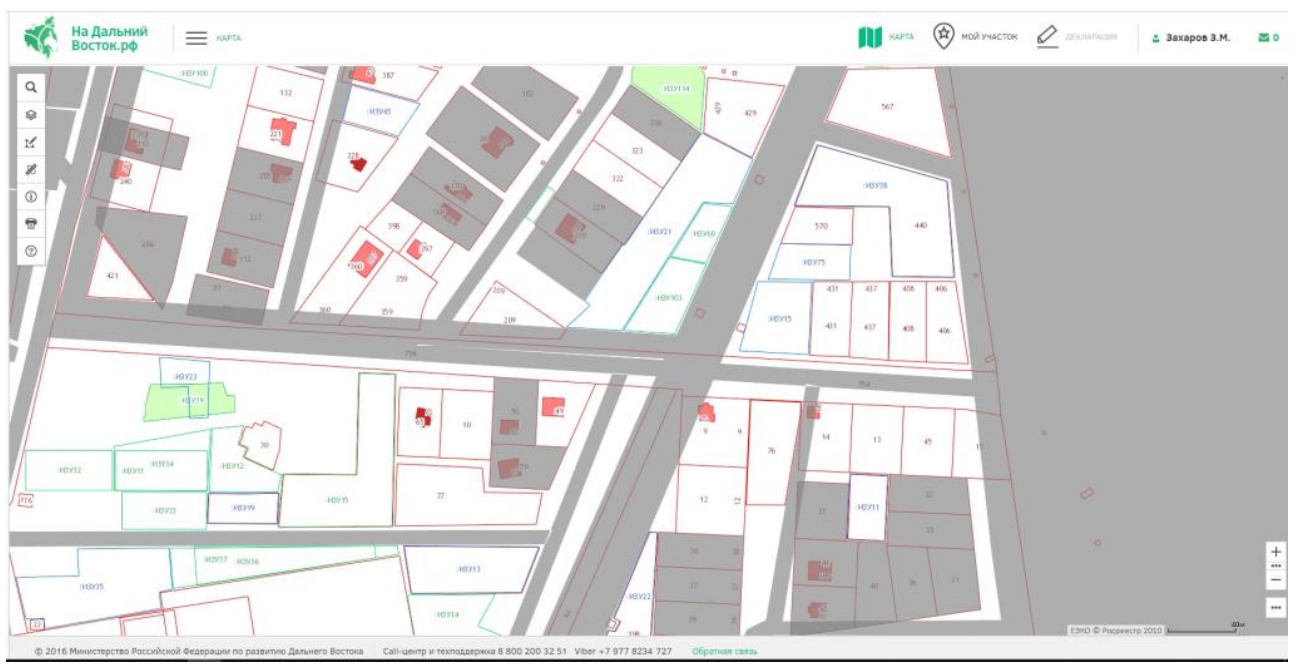

Fig. 4. The Federal information system "To the far East" [9].

One of the most pressing problems at the moment is that many landowners have not established the boundaries of their land. This leads to the fact that their land may be given to others as free hectares. [10]

The system has great functionality. The launch of the Federal information system "To the far East" is an important stage in the development of Russian information systems for the provision of public services.

Table 1. The comparison of existing information systems with the proposed concept.

\begin{tabular}{|c|c|c|c|c|c|}
\hline № & The Characteristic & 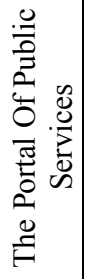 & 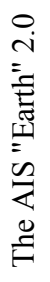 & 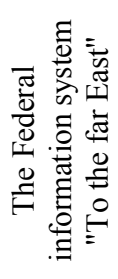 & 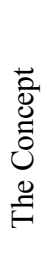 \\
\hline 1 & $\begin{array}{l}\text { The Connection to the Unified identification and } \\
\text { authentication system }\end{array}$ & + & - & + & + \\
\hline 2 & The Connection to the Unified state register of real estate & + & - & + & + \\
\hline 3 & Availability of an interactive electronic map & - & - & + & + \\
\hline 4 & Valid throughout the Russian Federation & + & - & - & + \\
\hline 5 & $\begin{array}{l}\text { The possibility of filing any applications for the provision } \\
\text { of land }\end{array}$ & + & - & - & + \\
\hline 6 & $\begin{array}{l}\text { The possibility to choose designated free and usable state } \\
\text { and municipal land plots }\end{array}$ & - & - & - & + \\
\hline 7 & $\begin{array}{l}\text { The sending automatic notifications to the authorized } \\
\text { bodies on the need to conduct auctions for the provision of } \\
\text { free and usable land }\end{array}$ & - & - & - & + \\
\hline
\end{tabular}


According to table 1, the main drawback of the existing systems is the limitation of a certain territory and a set of services. Also, the work of existing systems is aimed only at the provision of services, and not on land management.

Researcher A. Ilinykh notes that it is still necessary to use geographic information systems for land monitoring. For this, geographic information systems must take into account the time factor. [11]

One of the applications of GIS in ecology is the collection and management of data on protected areas, such as national parks, reserves and reserves. Within the protected areas, it is possible to conduct full-scale spatial monitoring of plant communities, valuable animal species, determine the impact of anthropogenic interventions (tourism, road construction or transmission lines), plan and implement environmental protection measures. [12]

Also, GIS-technologies allow to constantly update and refine the data in the process of design and construction, therefore, they allow the user to independently conduct real monitoring of territorial activity. [13]

The development of automated information technology based on the existing nonautomated technology is unprofitable and inefficient. The novelty element determines the effectiveness of a new automated technology. [14]

Scientists of Kazakhstan similarly note that it is necessary to create a Unified economic cadastre, having as its object the production factor "land", including all the natural resources involved in production. [15]

\section{Conclusion}

The concept of a new information system for the provision of electronic services in the field of land and property relations is the deep integration of various sectoral systems based on spatial information. It is necessary to ensure the possibility of providing services by authorities at all levels, not only on the portal of public Services, but also in an interactive form on geoinformation maps. The information system should shift the vector from the declarative nature of the provision of services to the management of land resources by stimulating the authorities to involve land in economic turnover.

\section{References}

1. The Program "Digital economy of the Russian Federation", approved by order of the Government of the Russian Federation from 28.07.2017 № 1632-p

2. The Strategy of information society development in Russian Federation to 2017 - 2030 , approved by decree of the President of the Russian Federation from 9.05.2017 № 203

3. The State (national) report on the state and use of land in the Russian Federation in 2017

4. Y. Mironova, Actual Problems of the Humanities and Natural Sciences 1 (2014)

5. The Public cadastral map, https://pkk5.rosreestr.ru (reference date 18.04.2019)

6. E. Khlebnikova, O. Miroshnikova, Interexpo Geo-Siberia, 3, 12-17 (2017)

7. I. Karpov, Modern scientific researches and innovations 10(78), 12 (2017)

8. The Automated information system of registration of citizens for the provision of land for individual housing construction, https://aiszem.krtech.ru (reference date 18.04.2009)

9. The Federal information system to provide citizens with land plots, https://надальнийвосток.pф (reference date 18.04.2019) 
10. E. Tkachenko, Basic research 1, 133-137

11. A. Ilinykh, Journal of higher educational institutions. Geodesy and aerial photography 1, 34-36 (2010)

12. T. Rudich, O. Tkacheva, International Student Science Journal 4(4) (2016)

13. O. Zakabluk, Scientific journal "Student Forum" 13(3) (2017)

14. V. Vasiliev, Young scientist 14, 62-66 (2016)

15. V. Akimov, M. Jarbusynova, E. Madumarova, O. Music, Way of science 5(27), 51-55 (2016) 